\title{
Description of a new marine predatory nematode Latronema dyngi sp. nov. (Nematoda, Chromadorida, Selachinematidae) from the west coast of Sweden and an updated phylogeny of Chromadoria
}

\author{
Mohammed Ahmed $^{1}$ (D) - Oleksandr Holovachov ${ }^{1}$ (D) \\ Received: 3 July 2020 / Revised: 8 October 2020 / Accepted: 15 October 2020 / Published online: 25 November 2020 \\ (C) The Author(s) 2020
}

\begin{abstract}
A new nematode species, Latronema dyngi sp. nov., is described from Skagerrak off the west coast of Sweden with the type locality near Dyngö island. Latronema dyngi sp. nov. is characterized by multispiral amphideal fovea with circular outline, $0.2-$ 0.3 corresponding body diameters wide in males and $0.1-0.2$ corresponding body diameters wide in females, 12 cuticular longitudinal ridges and 18-27 precloacal supplements in males. Latronema dyngi sp. nov. most closely resembles L. orcinum in terms of body length; demanian ratios a, b, c and c'; number of amphid turns in males; and the ratio of spicule length to cloacal body diameter. The two species can be differentiated by the number longitudinal ridges on the cuticle (12 for Latronema dyngi sp. nov. vs 20-22 for L. orcinum) and spicule length (65-78 $\mu \mathrm{m}$ for $L$. dyngi vs 60 for L. orcinum) and shape (weakly arcuate for L. dyngi sp. nov. vs strongly arcuate for L. orcinum). We also performed a maximum likelihood phylogenetic analysis on over 250 nematodes of the subclass Chromadoria based on their nearly full-length $18 \mathrm{~S}$ rDNA sequences. In agreement with previous studies, our analysis supported Selachinematidae as a monophyletic group and placed Richtersia Steiner, 1916 within Desmodoridae Filipjev, 1922 or just outside of the main Desmodorida clade with the latter placement not well supported.
\end{abstract}

Keywords Dyngö $\cdot$ Skagerrak $\cdot$ Choniolaiminae $\cdot$ Longitudinal ridges $\cdot$ Amphideal fovea

\section{Introduction}

The genus Latronema Wieser, 1954 belongs to a family of predatory marine nematodes called Selachinematidae Cobb, 1915. Species of the family are characterized by wide stoma with armament that aids them in preying on other nematodes. The family currently comprises 13 genera grouped into two subfamilies, Choniolaiminae Schuurmans Stekhoven \& Adam, 1931 and Selachinematinae Cobb, 1915. Latronema belongs to the subfamily Choniolaiminae whose members are

This article is registered in ZooBank under http://zoobank.org/ 8C027049-96A3-481F-94C8-9810E7682ACA

Communicated by M. Schratzberger

Mohammed Ahmed

mohammed.ahmed@nrm.se

1 Department of Zoology, Swedish Museum of Natural History, Box 50007, SE-104 05 Stockholm, Sweden characterized by a stoma with broad, cup-shaped anterior chamber and a narrow, cylindrical posterior chamber.

The first species of the genus Latronema was Latronema aberrans (Allgén, 1934), described then as a species of the genus Paracanthonchus Micoletzky, 1924 from Öresund. Wieser (1954) later established the genus Latronema with the description of L. piratica Wieser, 1954 and transferred two species, L. orcinum (Gerlach, 1952) and L. annulatum (Gerlach, 1953), both previously described under the genus name Synonchiella Cobb, 1933. Subsequently, Gerlach (1964a) moved Paracanthonchus aberrans to Latronema and provided a redescription of the species based on specimens from Kiel Bay. The genus currently consists of eleven species, but Latronema aberrans remains the only species ever recorded in Sweden until now.

Relationships within the family have been poorly defined for a long time because understanding of the buccal structure has been insufficient for most of the genera within the family (Wieser 1954; Gerlach 1964b). Later attempts to clarify relationships within the family involved the use of molecular data 
(Leduc and Zhao 2015). These analyses did not support the division of the family into Choniolaiminae and Selachinematinae. They also showed that Latronema and Richtersia Steiner, 1916 were not closely related, which was in contrast with Lorenzen (1981) who based his decision to place Richtersia together with other Selachinematidae solely on its morphological similarities with Latronema - in having setiform anterior sensilla and longitudinal ridges along the body. In fact, according to the 28S rDNA-based phylogeny by Leduc and Zhao (2015), there was no indication of close relationship between Richtersia and the family Selachinematidae. In a more recent analysis of the relationships between Richtersia and other members of the order Desmodorida using the $18 \mathrm{~S}$ rDNA, Gharahkhani et al. (2020) concluded that Richtersia belonged to Desmodorida and not Selachinematidae or an intermediate taxon between Selachinematidae and Desmodoroidea as previously proposed (Lorenzen 1981; De Ward and Russo 2007; Neira and Decraemer 2009). This is in agreement with some much earlier suggestions to classify Richtersia within Desmodorida (Chitwood and Chitwood 1950; De Coninck 1965; Gerlach and Riemann 1973).

While Leduc and Zhao (2016) improved the phylogenetic hypothesis with the addition of a few more species, a great majority of the genera of the family remained unaccounted for, and most important among these absent genera was Gammanema Cobb, 1920. Morphologically, Latronema appears to be most closely related to Gammanema. The two have similar buccal structure, arrangement of buccal armaments, tail shape, and presence of circular membrane surrounding the lip. In fact, this has been proven in a recent phylogenetic analysis based on both the $18 \mathrm{~S}$ and $28 \mathrm{~S}$ rDNA which revealed a close relationship between the two genera (Ahmed et al. 2020).

Here, we describe a new species of Latronema recovered from several localities in Skagerrak on the west coast of Sweden, collected during 2011, 2014, and 2019. Additionally, we present an analysis of the phylogenetic relationship between members of the family Selachinematidae and Richtersiidae represented by Richtersia, as well as a large selection of marine nematodes of the subclass Chromadoria.

\section{Material and methods}

\section{Sampling}

In 2011, 2014, and 2019, bottom sediment samples were collected from several locations on the west coast of Sweden. Locations included Dyngö (2019), Storö (2019), Bonden (2011), and Hållö (2014). All samples were collected with a bottom dredge and further sieved in the laboratory before fixation. Nematodes were extracted from samples using a decanting and sieving method (smallest mesh sizes: $45 \mu \mathrm{m}$ or $70 \mu \mathrm{m}$ ). Freshwater was used during sieving to induce an osmotic shock in nematodes inducing their detachment from the substrate. Material retained on the sieves was immediately fixed in a $4 \%$ formaldehyde solution in freshwater or in $95 \%$ ethanol. For light microscopy, formaldehyde-preserved specimens were transferred to pure glycerine using Seinhorst (1959) rapid method as modified by De Grisse (1969). Permanent nematode mounts on glass slides were prepared using the paraffin wax ring method. All curved structures were measured along the curved median line. Measurements in all tables are presented in $\mu \mathrm{m}$ as mean and range where appropriate. Terminology follows Maggenti (2005). Abbreviations are according to Hunt and Palomares-Rius (2012). Specimens are deposited in the invertebrate collection of the Department of Zoology, Swedish Museum of Natural History, Stockholm, Sweden (SMNH).

\section{Molecular analysis}

Detailed description of DNA extraction, polymerase chain reaction, sequencing, and phylogenetic analysis are presented in Ahmed et al. (2020). Briefly, purified DNA was extracted from single specimens using the Qiagen QiAmp DNA Micro kit (Qiagen, Sollentuna, Sweden). The nearly full-length $18 \mathrm{~S}$ rDNA ( 1800 bp) was amplified using Illustra Hot Start Mix RTG $0.2 \mathrm{ml}$ reaction kit (GE Healthcare Life Sciences, Sweden) and subsequently purified using exonuclease I and shrimp alkaline phosphatase (New England Biolabs, MA, USA). The purified products were sent to Macrogen Europe B.V. (Amsterdam, Netherlands) to be sequenced. Alignment from Ahmed et al. (2020) was expanded with addition of newly generated and publicly available sequences. Editing of the secondary structure annotations of the aligned sequences was performed using the JAVA-based editor 4SALE (Seibel et al. 2006). Using RAxML-HPC2 on XSEDE version 8.2.12 (Stamatakis 2014) run on CIPRES Science Gateway (Miller et al. 2010), a maximum likelihood tree was reconstructed from the alignments with secondary structure annotations.

\section{Results}

\section{Systematics}

Family Selachinematidae Cobb, 1915

Genus Latronema Wieser, 1954 emended Gerlach 1964a, Tchesunov 2014 and Leduc and Zhao 2015

Type species. Latronema orcinum Gerlach, 1953

Generic diagnosis: Body stout, cylindrical, anterior end abruptly truncated. Cuticle complex, with fine but distinct annulations interrupted by $12-50$ longitudinal ridges along 
most of the length of the body, becoming indistinct or irregular in arrangement towards the anterior end. Body annules appearing as either punctations or transverse ribbings separated into sections by the longitudinal ridges. Lateral differentiation absent. Somatic setae scattered along the body, beginning from immediately posterior to the base of the amphid and extending to the tail region. Labial region consisting of circular membrane with fine longitudinal streaks. All anterior sensilla setiform. There are six inner labial setae and a single circle of 10 outer labial and cephalic setae (14 in L. orcinum). Amphideal fovea often small, transversely or longitudinally oval, spiral or rounded in shape, and often obscure (Table 1). Buccal cavity consists of two chambers. Anterior chamber wide with 12 cuticularized rugae each of which terminates posteriorly in a pointed tooth. Posterior chamber smaller, conical to almost cylindrical, wider anteriorly. Pharynx cylindrical, muscularized, with no distinct anterior or posterior swelling. Precloacal supplements sucker-like or cup-shaped. Tail conical in shape.

Latronema dyngi sp. nov.

http://zoobank.org/EDB98913-5701-4EA1-9ABAAEFEDEAFEF44

Table 2; Figs. 1, 2 and 3

Type material. Holotype male (slide \# SMNH Type-9284) and 25 male and 35 female paratypes (slides \# SMNH Type9285 - SMNH Type-9295) deposited in the type invertebrate collection of the Department of Zoology, Swedish Museum of Natural History (Stockholm, Sweden).

Additional material: Six males and five females (slides \# SMNH-185989 - SMNH-185996 and SMNH-182042) deposited in the general invertebrate collection of the Department of Zoology, Swedish Museum of Natural History (Stockholm, Sweden).

GenBank accession numbers: MN786721-MN786741, MT846144-MT846162, and MW078504-MW078532.

Diagnosis. Latronema dyngi sp. nov. characterized by $1.3-$ $1.8 \mathrm{~mm}$ long body; two circles of anterior sensilla, six setiform inner labial sensilla in the anterior circle, and ten setiform outer labial and cephalic sensilla in the posterior circle; cephalic sensilla longer than outer labial sensilla; amphidal fovea multispiral in shape with circular outline, sexually dimorphic, 1.5-2.5 turns in males and 1.25-2.25 turns in females, $0.2-0.3$ corresponding body diameters wide in males and $0.1-$ 0.2 corresponding body diameters in females; cuticular longitudinal ridges 12 in number; precloacal supplements ranging between 18 and 27 in number $(n=19)$, spicule $60-78 \mu \mathrm{m}$ in length.

Description. Adult characters: Body cylindrical, with truncated anterior end but tapers slightly towards the posterior end. Cuticle with transverse striations and longitudinal rows of ridges numbering around 12 at the midbody region. Cuticular ornamentation appearing as transverse rows of punctations most apparent at the head region (Fig. $2 \mathrm{~d}$ and Fig. $3 b)$. Somatic setae arranged in two rows in ventrosublateral and dorsosublateral positions along the entire body. Labial region setoff, slightly narrower and marked by fine longitudinal grooves starting from the base of the lip up to the stoma opening. Anterior sensilla arranged in two circles as follows: $(6+(6+4))$. Inner labial sensilla setiform, located on the edge of the circular labial membrane. Outer labial sensilla small setiform $(7-12 \mu \mathrm{m})$, located at the base of the labial region. Cephalic sensilla setiform $(13-20 \mu \mathrm{m})$, equal to 0.3 0.5 labial region diameters in length, located at the same level as outer labial sensilla. Amphideal fovea lateral, sexually dimorphic, multispiral with 1.5-2.5 turns in males and 1.252.25 turns in females, with circular outline, equal to about $0.2-0.3$ of the corresponding body diameter in males and $0.1-0.2$ in females. Buccal cavity voluminous, divided into anterior and posterior chambers. Anterior chamber of buccal cavity barrel-shaped, with 12 cuticularized rugae terminating into three sets of large teeth. Their arrangement follows the triradial symmetry of the buccal cavity. Each set consists of single horizontal row of four blunt-ended, posteriorly pointing teeth (see arrows "b" in Figs. 2a and 3a). At the center of and slightly anterior to each set of the four teeth, there is also a single prominent tooth with tapered end and pointing horizontally (see arrow "a" in Figs. 2a and 3a) making a total of five teeth set on each of the three walls of the buccal cavity. Posterior buccal chamber almost cylindrical in shape, but slightly wider at anterior extremity with six cuticularized rectangular "rhabdions" (Fig. 2a). Oblique strands of muscles present around the anterior chamber of the stoma (Fig. 2b). They appear to stretch from the anterior ends of cuticularized rhabdions to the stoma wall at the level of the base of the anterior stoma. These muscles may be involved in the eversion of the stoma which occurs during the seizure of a prey. Pharynx muscularized, with developed glandular tissue throughout its entire length, with no conspicuous anterior or posterior bulb. Cardia present. Secretory-excretory system not observed; nerve ring at $33-46 \%$ of the length of the pharynx. Tail short conical and slightly ventrally curved. Caudal glands present, opening via a common spinneret; caudal gland cells/ bodies may extend anterior to the posteriormost end of intestine.

Males: Reproductive system diorchic, with outstretched anterior testis and reflexed posterior testis situated ventrally to the intestine. Spicules paired and symmetrical, slightly arcuate, equal to 1.1-1.3 anal body diameters in length. Gubernaculum paired, appearing as small bars parallel to the distal part of the spicule. Single midventral precloacal setiform sensillum located $12-17 \mu \mathrm{m}$ from the cloacal opening. Precloacal supplements present, sucker-like, immediately following the midventral seta and numbering between 18 and 27 .

Females: Reproductive system didelphic, amphidelphic, ovary branches reflexed antidromously. Anterior ovary on 


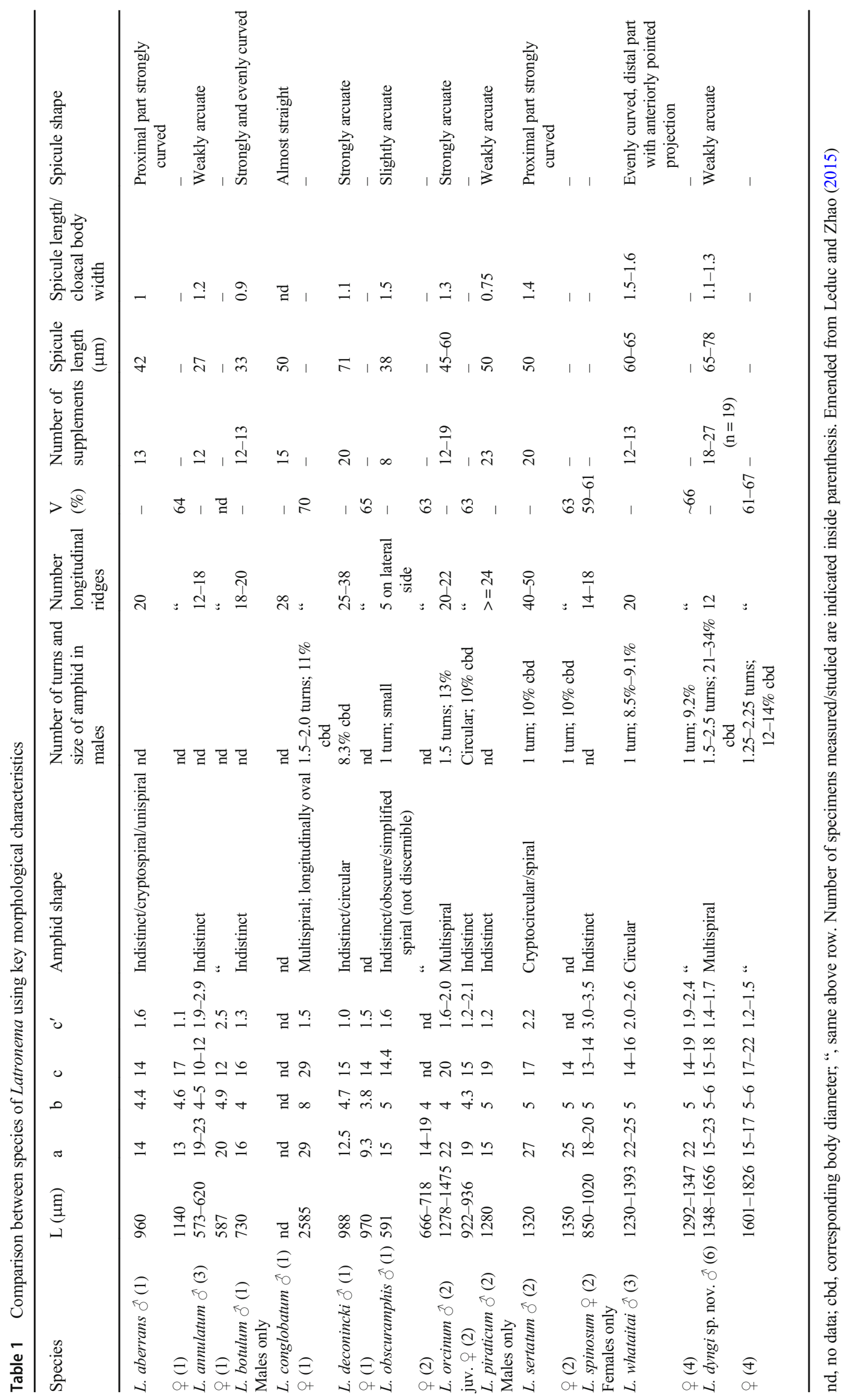


Table 2 Morphometrics of males and females of Latronema dyngi sp. nov.

\begin{tabular}{|c|c|c|c|}
\hline Character & Holotype & Male paratypes & Female paratypes \\
\hline $\mathrm{N}$ & & 6 & 4 \\
\hline $\mathrm{L}$ & 1501.5 & $1508(1348-1656)$ & 1709 (1601-1826) \\
\hline $\mathrm{a}$ & 18.4 & $18(15-23)$ & $16(15-17)$ \\
\hline $\mathrm{b}$ & 5.9 & $5.5(5.3-5.9)$ & $5.5(5.3-5.8)$ \\
\hline $\mathrm{c}$ & 15.3 & $16(15-18)$ & $19(17-22)$ \\
\hline$c^{\prime}$ & 1.7 & $1.6(1.4-1.7)$ & $1.3(1.2-1.5)$ \\
\hline $\mathrm{V}(\%)$ & - & - & $64(61-67)$ \\
\hline Labial region diameter & 42.64 & $45(39-51)$ & $47(37-55)$ \\
\hline Body diameter at level of amphid & 53.56 & $57(53-62)$ & $68(62-72)$ \\
\hline Outer labial sensilla length & 7.28 & $8(7-9)$ & $10(8-12)$ \\
\hline Cephalic sensilla length & 12.48 & $16(13-19)$ & $19(18-20)$ \\
\hline Cephalic sensilla base to anterior end & 9.88 & $10(8-11)$ & $14(11-16)$ \\
\hline Subcephalic sensilla length & 16.12 & $18(16-19)$ & $21(16-23)$ \\
\hline Amphid from anterior end & 14.04 & $18(14-22)$ & $20(17-24)$ \\
\hline Amphid width & 14.56 & $13(10-16)$ & $10(8-10)$ \\
\hline Distance from anterior end to base of anterior stoma & 16.12 & $20(16-23)$ & $23(21-26)$ \\
\hline Length of posterior stoma chamber & 13.52 & $17(14-25)$ & $20(17-26)$ \\
\hline Distance from anterior end to base of posterior stoma & 29.64 & $37(30-44)$ & $45(40-48)$ \\
\hline Nerve ring from anterior end & 86 & $105(86-130)$ & $138(110-157)$ \\
\hline Pharyngeal region length & 255 & $274(236-304)$ & $310(287-337)$ \\
\hline Maximum body diameter & 81 & $85(68-109)$ & $109(102-119)$ \\
\hline Spicule length along arc & 70.38 & $70(65-78)$ & - \\
\hline Gubernaculum length & 15 & $21(18-26)$ & - \\
\hline Anal body diameter & 56.58 & $59(54-66)$ & $69(59-84)$ \\
\hline Tail length & 97.98 & $93(77-105)$ & $90(73-103)$ \\
\hline Amphid width/corresponding body diameter (\%) & 34.1 & $29(21-34)$ & $14(12-16)$ \\
\hline Nerve ring from ant. end/pharyngeal region length (\%) & 33.5 & $38(33-43)$ & $41(36-46)$ \\
\hline Cephalic sensilla length/lip region diameter & 29.3 & $35(29-43)$ & $42(36-48)$ \\
\hline
\end{tabular}

right of intestine, posterior ovary on left of intestine. Vulva located just posterior to midbody, at $61-67 \%$ body length. Further detail of the female reproductive system was difficult to observe due to the suboptimal conditions of most of the females after fixation. Pars proximalis vaginae longer than wide and joins the uteri at about a third of the corresponding body diameter. Pars refringens vaginae flattened and barshaped (Fig. 2c).

Etymology. The specific name denotes the type locality, Dyngö on the west coast of Sweden.

Type locality. Västra Götalands län, Dyngö Island, 4.4$7.2 \mathrm{~m}$ deep, coarse sand and shell gravel, N 58 $36.590^{\prime}-$ $58^{\circ} 36.571^{\prime}$ E $11^{\circ} 11.447^{\prime}-11^{\circ} 11.540^{\prime}$, coll. O. Holovachov, M. Ahmed \& U. Jondelius, 20-09-2019

Additional localities. Storö (2019); Bonden (2011); Hållö (2014). Västra Götalands län, Bonden Island, 15$22 \mathrm{~m}$ deep, coarse sand and shell gravel, N 58 $12^{\prime} 37.41^{\prime \prime}$ E $11^{\circ} 18^{\prime} 53.19^{\prime \prime}$, coll. O. Holovachov \& M. Clement, 09-
08-2011. Västra Götalands län, Hållö Island, 14-17 m deep, coarse sand and shell gravel, N 58 $20.38^{\prime}-58^{\circ} 20.32^{\prime}$ E $11^{\circ} 12.73^{\prime}-11^{\circ} 12.68^{\prime}$, coll. O. Holovachov \& U. Jondelius, 19-08-2014. Västra Götalands län, Storö Island, 10.2-12.7 m deep, coarse sand and shell gravel, $\mathrm{N}$ $58^{\circ} 34.660^{\prime}-58^{\circ} 34.665^{\prime} \mathrm{E} 11^{\circ} 03.721^{\prime}-11^{\circ} 03.722^{\prime}$, coll. M. Ahmed \& U. Jondelius, 03-07-2019.

Remarks. Latronema dyngi sp. nov. can be differentiated from L. orcinum (Gerlach, 1952), which it most closely resembles, by the number of longitudinal ridges on the cuticle (12 for Latronema dyngi sp. nov. vs 20-22 for $L$. orcinum) and spicule length (65-78 $\mu \mathrm{m}$ for $L$. dyngi vs 60 for $L$. orcinum) and shape (weakly arcuate for $L$. dyngi sp. nov. vs strongly arcuate for L. orcinum). The new species $(1348-1826 \mu \mathrm{m})$ is different in terms of body length from $L$. annulatum (Gerlach, 1953) (573$620 \mu \mathrm{m})$, L. botulum Gerlach, $1956(730 \mu \mathrm{m})$, L. deconincki

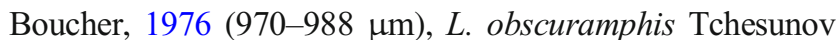
Jeong \& Lee, 2020 (591-718 $\mu \mathrm{m})$, L. spinosum Andrássy, 

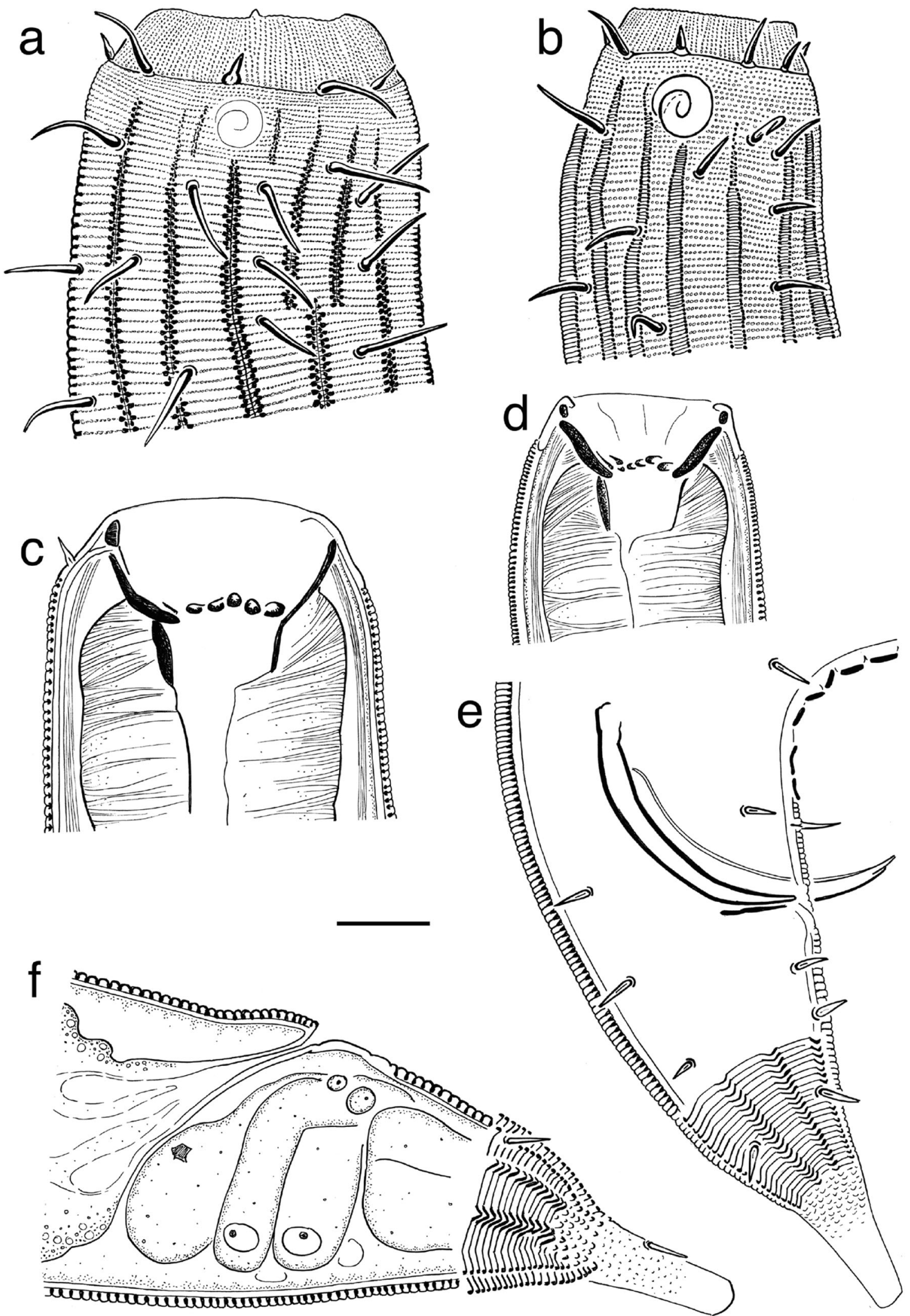

Fig. 1 Latronema dyngi sp. nov.: a Surface view of a female paratype head region; b surface view of a male holotype head region; c Female paratype head region, median section showing buccal cavity; d Male holotype head region, median section showing buccal cavity; e
Posterior end of a male showing spicules (left spicule partially protruded) and gubernaculum; f Posterior end of a female. Scale bar = $20 \mu \mathrm{m}$ 
1973 (850-1020), and L. conglobatum Gerlach, 1964 (Gerlach 1964b) $(2585 \mu \mathrm{m})$ (Table 1). The new species can also be distinguished from $L$. aberrans by the number of supplements (13 vs 18-27 for L. dyngi sp. nov.), spicule length (42 $\mu \mathrm{m}$ vs $65-$ $78 \mu \mathrm{m}$ ), and spicule shape (proximal part acutely arcuate vs weakly and uniformly arcuate in $L$. dyngi sp. nov.); from $L$. conglobatum by the number of supplements (15 vs 18-27 for L. dyngi sp. nov.), number of longitudinal ridges (28 vs 12 for L. dyngi sp. nov.), and spicule length (50 vs 65-78 for L. dyngi sp. nov.); and from $L$. whataitai Leduc \& Zhao, 2015 by the number of supplements (12-13 vs 18-27 for L. dyngi sp. nov.) and number of longitudinal ridges (20 vs 12 for $L$. dyngi sp. nov.).

Latronema dyngi sp. nov. differs from $L$. piraticum Wieser, 1954 and L. sertatum Wieser, 1959 in number of longitudinal ridges ( $>=24$ for $L$. piraticum and 40-50 for L. sertatum vs 12 for $L$. dyngi sp. nov.) and in spicule length $(50 \mu \mathrm{m}$ for L. piraticum and $50 \mu \mathrm{m}$ for $L$. sertatum vs $65-78 \mu \mathrm{m}$ for L. dyngi sp. nov.).

Females of $L$. dyngi sp. nov. can also be distinguished from the holotype of $L$. spinosum in the tail length in relation to anal body diameter ( $\mathrm{c}^{\prime}=3.0-3.5$ vs $1.2-1.5$ for $L$. dyngi sp. nov.).

\section{Discussion and molecular phylogeny}

The new species Latronema dyngi sp. nov. represents the second species of the genus to be recorded in Sweden, after Latronema aberrans. The two can easily be distinguished on the basis of the number of precloacal supplements they possess, spicule length, number of longitudinal ridges, etc. (Table 1).

The data presented here on Latronema orcinum is based on the descriptions of populations from Kiel Bay, Germany (Gerlach 1952), the Maldives (Gerlach 1964b), and Sylt, Germany (Blome 1974). The most striking difference between the populations is in the spicules size where those described from Sylt possessed spicule almost twice the size of that from the ones described from Kiel Bay ( $80 \mu \mathrm{m}$ vs $45-48 \mu \mathrm{m})$. The male population from the Maldives also has fewer precloacal supplements than the two other populations (12-13 vs 17 in Sylt population and 19 in Kiel Bay population). Body length, on the other hand, is similar across the populations. We suspect that these populations could be different species. A similar observation was made with the two Gammanema rapax
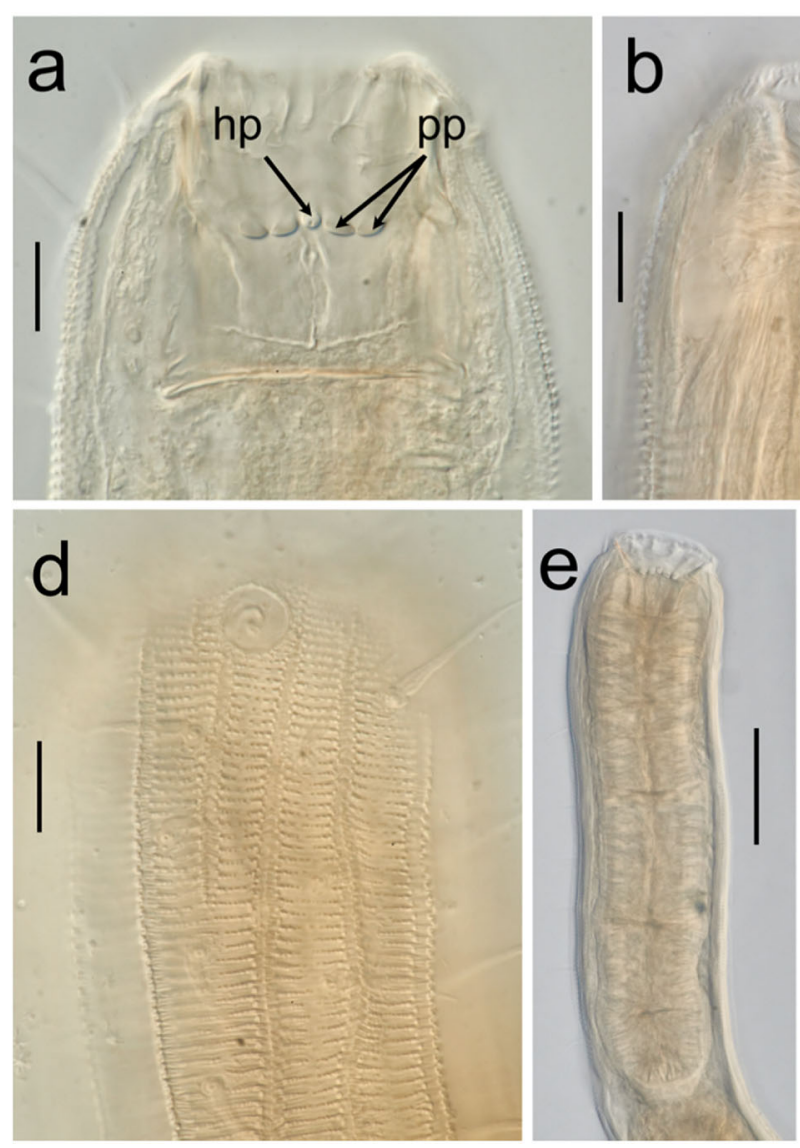

Fig. 2 Latronema dyngi sp. nov.: a Female head region showing buccal armament: single horizontally pointed tooth (hp), posteriorly pointed teeth (pp); b Anterior end of a female showing muscular arrangements; c Midbody region showing pars proximalis vaginae (ppv) and pars
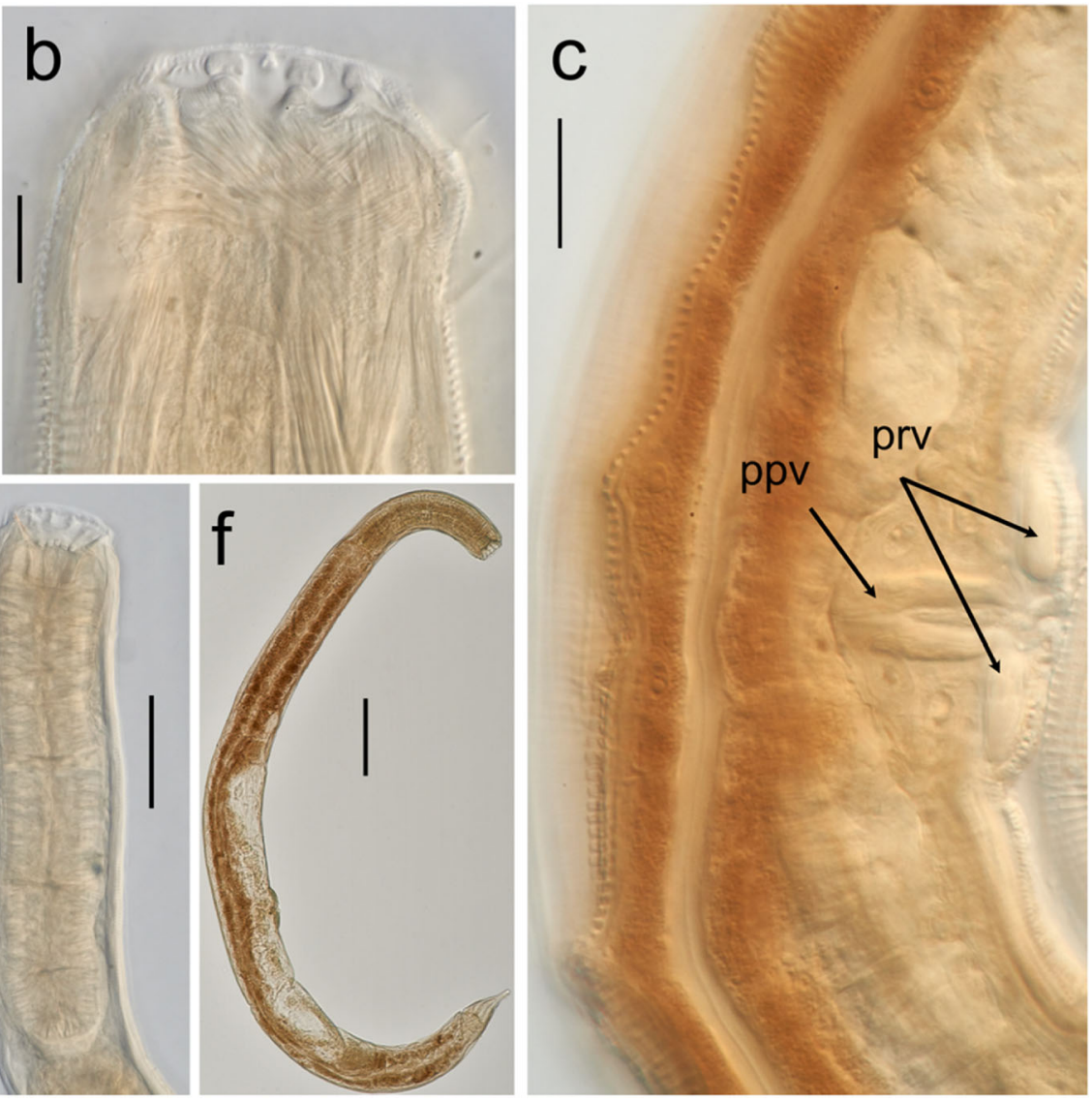

refringens vaginae (prv); d Surface view of a female head region showing amphid and cuticular ornamentations; e Female anterior region showing the pharynx; f Full body of a female. Scale bar A-C $=20 \mu \mathrm{m}, \mathrm{D}=$ $100 \mu \mathrm{m}, \mathrm{E}=200 \mu \mathrm{m}$ 

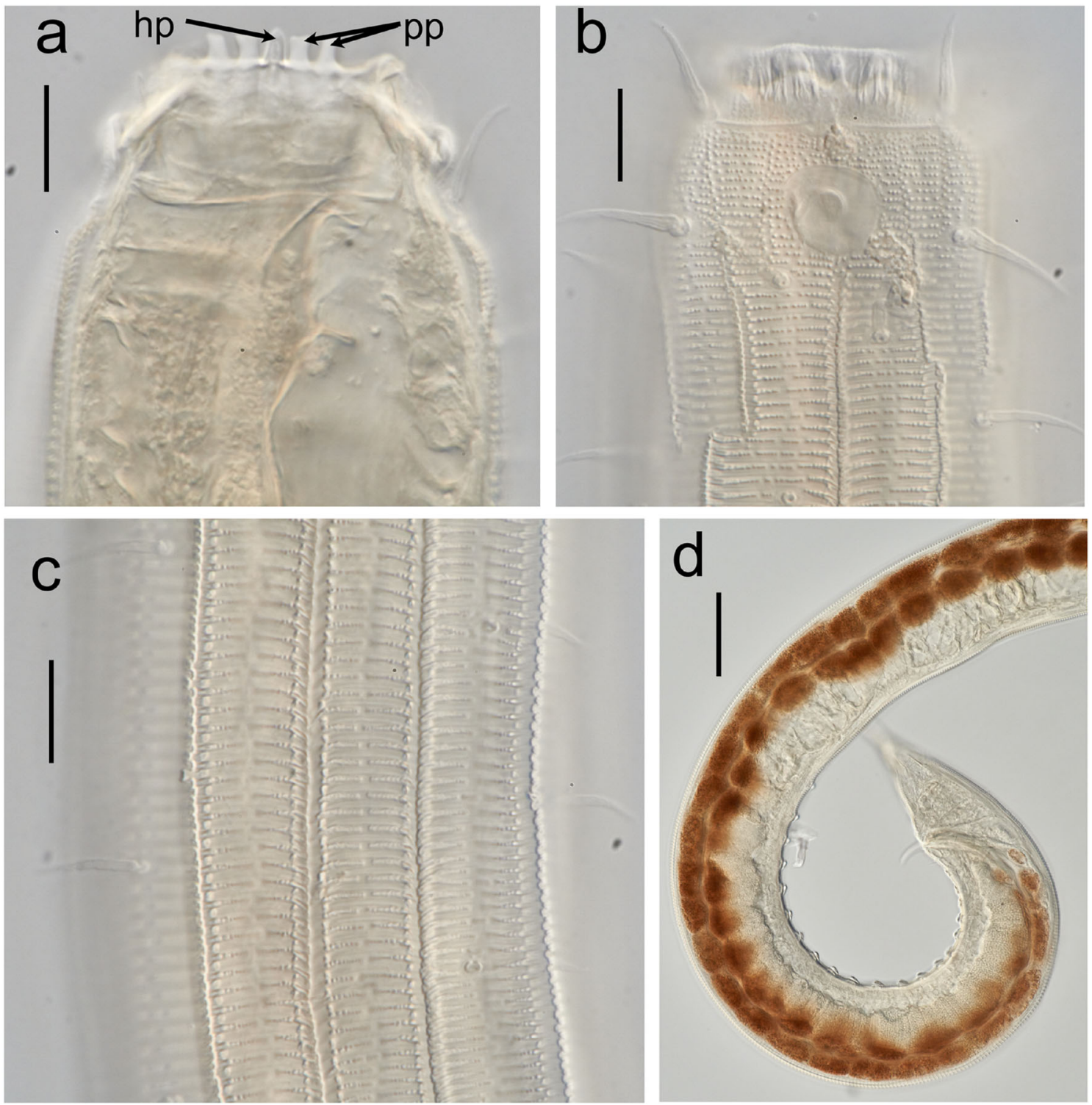

Fig. 3 Latronema dyngi sp. nov.: a Male head region showing buccal armament with the stoma everted: single horizontally pointed tooth (hp), posteriorly pointed teeth (pp); b Surface view of a male head region showing the amphid and cuticular ornamentations; c Surface view of midbody region showing longitudinal ridges; $\mathbf{d}$ Male posterior region showing precloacal supplements. Scale bar $A-C=20 \mu \mathrm{m}, \mathrm{D}=100 \mu \mathrm{m}$
Ssaweljev, 1912 populations represented in the phylogenetic analysis herein. One population matched in most characters Gammanema rapax according to Okhlopkov (2002) which was similar in almost all characters, except body length, to the original description by Ssaweljev (1912). The other population resembled Gammanema rapax sensu Platt and Warwick (1988). According to our phylogenetic analysis, these are most likely different species, which would be in agreement with the conclusion made by Okhlopkov (2002).

In total, 266 published 18S rDNA sequences and newly generated ones (mostly nearly full-length) were used for reconstructing the phylogeny. Four taxa belonging to the subclass Dorylaimia were used as outgroups, namely Mermis nigrescens Dujardin, 1842, Mononchus aquaticus Coetzee, 1968, Nygolaimus cf. brachyuris, and Dorylaimus stagnalis Dujardin, 1845 . The secondary structure-based alignment resulted in 1961 characters including gaps. The branch consisting of Chromadorida was not well supported (Fig. 4). However, all Selachinematidae included in the analysis were placed in a moderately supported monophyletic clade (bs = 88) and formed sister clade to all other Chromadoroidea. The former observation is consistent with all previous analysis involving Selachinematidae (Gerlach 1964b; Leduc and Zhao 2015, 2016; Leduc et al. 2019; Gharahkhani et al. 2020). The characteristic two chambered stoma unique among Selachinematids was theorized by Gerlach (1964b) to have 


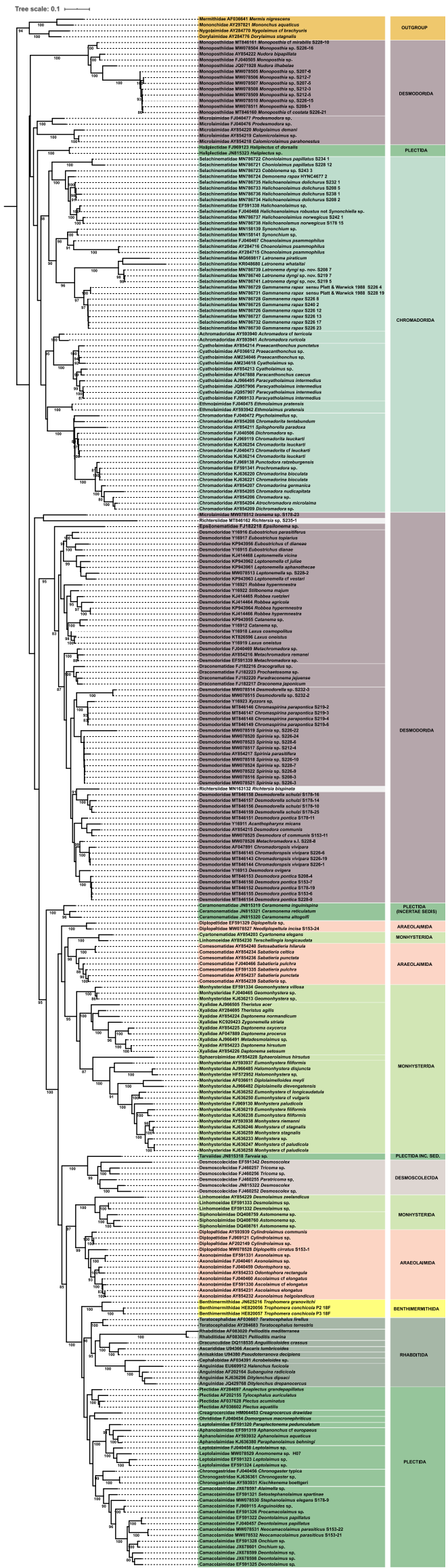

Fig. 4 Maximum likelihood phylogenetic tree of marine Chromadoria inferred from 18S rRNA data, using alignments based on secondary structure models using GTR GAMMA for unpaired sites and RNA7A for paired sites (based on Ahmed et al. (2020))

arisen from one resembling that of a Cyatholaimid, suggesting that the two are close relatives. However, the tree presents no evidence to suggest Selachinematids may have evolved from Cyatholaimidae Filipjev, 1918. In fact according to another $18 \mathrm{~S}$ rDNA-based analysis, the Selachinematidae lineage may have branched much earlier from all other Chromadorida, although the branching was not well resolved (Holterman et al. 2019). Gammanema and Latronema formed a strongly supported clade which conforms with their shared morphological characteristics such as buccal structure, presence of circumoral membrane, and tail shape. The branch formed by the new species was clearly separated from the other species of Latronema included in our analysis. Even though this phylogenetic delimitation is not a necessity here to confirm Latronema dyngi sp. nov. as previously undescribed - since this has been sufficiently demonstrated morphologically in this study - a tree with more representative set of species of Latronema will help understand better their within-group relationships.

Within the branch consisting of all the remaining Chromadoroidea Filipjev, 1917, Cyatholaimidae and Achromadoridae Gerlach \& Riemann 1973 were recovered as sisters and together formed a sister branch to a Chromadoridae Filipjev, 1917 + Ethnolaimidae Filipjev \& Schuurmans Stekhoven, 1941 branch.

Our analysis placed the recently described Richtersia bispinata Gharahkhani, Pourjam, Leduc, and Pedram, 2020 deep within a clade of only Desmodoridae similar to its placement in the original description (Gharahkhani et al. 2020). Also in congruence with the original description was the close relationship between Richtersia bispinata and Desmodorella Cobb, 1933. Our specimen of Richtersia, on the other hand, formed a lineage with Ixonema Lorenzen, 1971 with both essentially forming a sister branch to all other Chromadoria (Desmodorida, Monhysterida, Araeolaimida, Plectida, and Rhabditida) and was positioned between Chromadorida and Desmodorida. The disparate placement of the two Richtersia species in our analysis might stem from the fact that the published sequence of Richtersia bispinata was missing some bases at the $5^{\prime}$ end and a few at its $3^{\prime}$ end. Interestingly, the position of our specimen is somehow in support of earlier morphology-backed suggestions to consider Richtersiidae as an intermediate between Desmodoroidea and Selachinematidae (Lorenzen 1981; De Ward and Russo 2007; Neira and Decraemer 2009). It is worth mentioning, however, that our own Richtersia was positioned between all sampled Chromadorida (not just Selachinematidae) and 
Desmodoroidea. Moreover, the branch was not well supported (bs = 57). Nonetheless, the Chromadoroidea-Desmodoroidea intermediate position of Richtersiidae makes more morphological sense because members possess both Chromadorid and Desmodorid characteristics (Gharahkhani et al. 2020). Efforts are still ongoing to obtain more specimens of members of Richtersiidae for sequencing. The inclusion of more taxa, we are confident, will help confirm the true position of this family in relation to Chromadorids and Desmodorids.

Also consistent with the previous analysis was the placement of the plectid family Haliplectidae Chitwood, 1951 among the earliest branching families of Chromadoria such as Monoposthiidae Filipjev, 1934 and Microlaimidae Micoletzky, 1922 (Holovachov et al. 2012), explaining why this family is considered incertae sedis (Holovachov 2014).

In conclusion, while it is clear from this study and previous phylogenetic analysis of the family that Selachinematidae is a monophyletic group (Leduc and Zhao 2015, 2016; Gharahkhani et al. 2020), some of the relationships within this family are still not understood due to the lack of representation for some genera in phylogenetic analyses. More taxa will, therefore, need to be included in future analysis to help better understand these relationships.

Acknowledgments Sampling in the Skagerrak was conducted using vessels ("Skagerak," "Nereus," and "Oscar von Sydow") and facilities of the Sven Lovén Centre for Marine Sciences in Kristineberg and in Tjärnö.

Funding Open access funding provided by Swedish Museum of Natural History. This research was supported by two grants from the Swedish Taxonomy Initiative: "Systematics of Swedish free-living nematodes of the orders Desmodorida and Araeolaimida" and "Systematics of poorly known marine nematodes of the class Chromadorea from Sweden".

\section{Compliance with ethical standards}

Conflict of interest The authors declare that they have no conflict of interest.

\section{Ethical approval Not applicable.}

Sampling and field studies All necessary permits for sampling and observational field studies have been obtained by the authors from the competent authorities and are mentioned in the acknowledgements, if applicable. The study is compliant with CBD and Nagoya protocols.

Data availability The sequence data generated for the new species are available in GenBank repository, https://www.ncbi.nlm.nih.gov/ nucleotide. GenBank accession numbers are provided in the text.

Authors' contribution $\mathrm{OH}$ performed initial identification of specimens. MA did morphometric studies and phylogenetic analyses. OH developed the illustrations (drawings and pictures). MA wrote the manuscript. Both authors read and approved the manuscript.

Open Access This article is licensed under a Creative Commons Attribution 4.0 International License, which permits use, sharing, adaptation, distribution and reproduction in any medium or format, as long as you give appropriate credit to the original author(s) and the source, provide a link to the Creative Commons licence, and indicate if changes were made. The images or other third party material in this article are included in the article's Creative Commons licence, unless indicated otherwise in a credit line to the material. If material is not included in the article's Creative Commons licence and your intended use is not permitted by statutory regulation or exceeds the permitted use, you will need to obtain permission directly from the copyright holder. To view a copy of this licence, visit http://creativecommons.org/licenses/by/4.0/.

\section{References}

Ahmed M, Boström S, Holovachov O (2020) Revision of the genus Cobbionema Filipjev, 1922 (Nematoda, Chromadorida, Selachinematidae). Eur J Taxon 702:1-34. https://doi.org/10.5852/ ejt.2020.702

Allgén CA (1934) Weitere Nematoden aus dem Öresund. Folia Zool Hydrobiol 7:97-110

Andrássy I (1973) Nematoden aus Strand - und Höhlenbiotopen von Kuba. Acta Zool Acad Sci Hungaricae 19:233-270

Blome D (1974) Zur systematik von Nematoden aus dem Sandstrand der Nordseeinsel Sylt. Microfauna Meeresboden 33:1-25 (75-99)

Boucher G (1976) Nématodes des sables fins infralittoraux de la Pierre Noire (Manche occidentale) II. Chromadorida. Bull du Muséum Natl d' Hist Nat Série 3, no 352. Zool 245:25-61

Chitwood BG (1951) North American marine nematodes. Texas J Sci: $617-672$

Chitwood BG, Chitwood MB (1950) An introduction to nematology. Section I. anatomy., 2nd edn. Monumental printing company, Baltimore., Baltimore

Cobb NA (1915) Selachinema, a new nematode genus with remarkable mandibles. Contrib to a Sci Nematol 4:113-116

Cobb NA (1920) One hundred new nemas (type species of 100 new genera). Contrib to a Sci Nematol 9:217-343

Cobb NA (1933) New nemic genera and species, with taxonomic notes (Ed. by Margaret V. Cobb). J Parasitol 20:81-94

Coetzee V (1968) Southern African species of the genera Mononchus and Prionchulus (Mononchidae). Nematologica 14:63-76

De Coninck LA (1965) Classe des Nématodes-Systématique des Nématodes et sous-classe des Adenophorea. Trait Zool 4:586-681

De Grisse AT (1969) Redescription ou modification de quelques techniques utilisés dans l'études dęs nématodes phytoparaires. Meded Rijksfakulteit Landbouwwet Gent 34:351-369

De Ward CTP, Russo VL (2007) A review of the genus Richtersia (Nematoda: Selachinematidae): new species from Golfo San José and Golfo San Matías, Chubut (Argentina). J Mar Biol Assoc United Kingdom 87:1153-1160. https://doi.org/10.1017/ S0025315407056755

Dujardin F (1842) Memoire sur la structure anatomique des Gordius et d'un autre helminthe, le Mermis, qu'on a confondu avec eux. Ann des Sci Nat Paris, Zool 18:129-151

Dujardin F (1845) Histoire naturelle des helminthes ou vers intestinaux, Paris

Filipjev IN (1917) Novaia svobodnaia Nematoda iz Kaspiiskago moria Chromadorissa gen. nov. (Chromadoridae, Chromadorini). Un nematode libre nouveau de la mer Caspienne, Chromadorissa gen. nov. (Chromadoridae, Chromadorini). Rev Zool Russe 2:24-29

Filipjev IN (1918) Svobodnozhivushchiia morskiia nematody okrestnostei Sevastopolia. Vypusk I. [free-living marine nematodes in the vicinity of Sevastopol. Part I.]. Tr Osob Zool Lab Sevastopol Biol Stantsii Ross Akad Nauk 4:1-352 
Filipjev IN (1922) New data about free-living nematodes of the Black Sea. Trans Stavropol Agric Inst 1:83-42 (In Russian)

Filipjev IN (1934) The classiffication of the free-living nematodes and their relation to the parasitic nematodes. Smithson Misc Collect 89: $1-63$

Filipjev IN, Schuurmans Stekhoven JHJ (1941) A manual of agricultural helminthology. EJ Brill, Leiden

Gerlach SA (1952) Nematoden aus dem Küstengrundwasser. Abh mathnaturw Kl Akad Wiss Mainz 6:315-372

Gerlach SA (1953) Die Nematodenbesiedlung des Sandstandes und des Kustengrundwassers an der italienischen Kuste. 1. Systematischer Teil. Arch Zool Ital 37:517-640

Gerlach SA (1956) Die Nematodenbesiedlung des tropischen Brandungsstrandes von Pernambuco. Brasilianische MeeresNematoden II. Kieler Meeresforsch 12:202-218

Gerlach SA (1964a) Freilebende Nematoden aus dem Roten Meer. Kieler Meeresforsch 20:18-34

Gerlach SA (1964b) Revision der Choniolaiminae und Selachinematinae (freilebende Meeres-Nematoden). Mitt Hamb Zool Mus Inst:23-49

Gerlach SA, Riemann F (1973) The Bremerhaven checklist of aquatic nematodes. A catalogue of nematoda Adenophorea excluding the Dorylaimida. Veröffentlichungen des Instituts für Meeresforsch Bremerhaven 4:1-736

Gharahkhani A, Pourjam E, Leduc D, Pedram M (2020) A molecular phylogenetic reappraisal of Richtersiidae Kreis, 1929 (Desmodorida: Desmodoroidea), with two new species of intertidal nematodes from the Persian Gulf. Nematology 1:1-17. https://doi. org/10.1163/15685411-bja10010

Holovachov O (2014) Order Plectida Gadea, 1973. In: Schmidt-Raesa a (ed) handbook of zoology. Gastrotricha, Cycloneuralia and Gnathifera, volume 2: De Gruyter, Hamburg, pp 487-535

Holovachov O, Fadeeva N, De Ley IT et al (2012) Revision and phylogeny of Tarvaia Allgén, 1934 (Nematoda: Tarvaiidae). Nematology 14:677-708. https://doi.org/10.1163/156854112X627255

Holterman M, Schratzberger M, Helder J (2019) Nematodes as evolutionary commuters between marine, freshwater and terrestrial habitats. Biol J Linn Soc 128:756-767. https://doi.org/10.1093/ biolinnean/blz107

Hunt DJ, Palomares-Rius JE (2012) General morphology and morphometries of plant-parasitic nematodes. Pract plant Nematol:25-64

Leduc D, Zhao Z (2015) Latronema whataitai sp. n. (Nematoda: Selachinematidae) from intertidal sediments of New Zealand, with notes on relationships within the family based on preliminary $18 \mathrm{~S}$ and D2-D3 phylogenetic analyses. Nematology 17:941-952. https:// doi.org/10.1163/15685411-00002915

Leduc D, Zhao ZQ (2016) Molecular characterisation of five nematode species (Chromadorida, Selachinematidae) from shelf and upper slope sediments off New Zealand, with description of three new species. Zootaxa 4132:59-76. https://doi.org/10.11646/zootaxa. 4132.1.5

Leduc D, Fu S, Zhao ZQ (2019) New nematode species from the continental slope of New Zealand (Chromadorea, Microlaimida, and Chromadorida), and unexpected placement of the genus Molgolaimus Ditlevsen, 1921. Mar Biodivers 49:2267-2280. https://doi.org/10.1007/s12526-019-00961-z

Lorenzen S (1971) Ixonema sordidum gen. n., sp. n. (Microlaimidae, Nematoda) aus sublitoralem Grobsand bei Helgoland. Mar Biol 8: 267-269
Lorenzen S (1981) Entwurf eines phylogenetischen Systems der freilebenden Nematoden. Kommissionsverlag F. Leuwer

Maggenti AR (2005) Online dictionary of invertebrate zoology. digitalcommons.unl.edu

Micoletzky H (1922) Die freilebenden Erdnematoden. Arch für Naturgeschichte:1-650

Micoletzky H (1924) Letzter Bericht über freilebende Nematoden aus Suez. Sber Akad Wiss Wien Mathem-naturw Klasse

Miller MA, Pfeiffer W, Schwartz T (2010) Creating the CIPRES science gateway for inference of large phylogenetic trees. In: gateway computing environments workshop (GCE), 2010. Ieee, pp 1-8

Neira C, Decraemer W (2009) Desmotersia levinae, a new genus and new species of free-living nematode from bathyal oxygen minimum zone sediments off Callao, Peru, with discussion on the classification of the genus Richtersia (Chromadorida: Selachinematidae). Org Divers Evol 9:1-e1. https://doi.org/10.1016/j.ode.2008.09.004

Okhlopkov JR (2002) Free-living nematodes of the families Selachinematidae and Richtersiidae in the White Sea (Nematoda, Chromadorida). Zoosystematica Ross 11:41-55

Platt HM, Warwick RM (1988) Free-living marine nematodes. British Chromadorids Synopses of the British Fauna No 38

Seibel PN, Müller T, Dandekar T et al (2006) 4SALE-a tool for synchronous RNA sequence and secondary structure alignment and editing. BMC Bioinformatics 7:498. https://doi.org/10.1186/1471-2105-7498

Schuurmans Stekhoven JH, Adam W (1931) The freeliving marine nemas of the Belgian coast. Bull du Musée R d'Histoire Nat Belgique 49:1-58

Seinhorst JW (1959) A rapid method for the transfer of nematodes from fixative to anhydrous glycerin. Nematologica 4:67-69

Ssaweljev S (1912) Zur Kenntnis der freilebenden Nematoden des Kolafjords und des Relictensee Mogilnoje. Trav la Société des Nat Saint-petersbg 42:108-126

Stamatakis A (2014) RAxML version 8: a tool for phylogenetic analysis and post-analysis of large phylogenies. Bioinformatics 30:13121313. https://doi.org/10.1093/bioinformatics/btu033

Steiner G (1916) Freilebende Nematoden aus der Barentssee. Zool Jahrbücher 39:511-664

Tchesunov AV (2014) Order Chromadorida Chitwood, 1933. In: Schmidt-Raesa A (ed) Handbook of zoology, Gastrotricha, Cycloneuralia and Gnathifera, vol 2. De Gruyter, Hamburg, pp 373-398

Tchesunov A, Jeong R, Lee W (2020) Two new marine free-living nematodes from Jeju Island together with a review of the genus Gammanema Cobb 1920 (Nematoda, Chromadorida, Selachinematidae). Diversity 12:19. https://doi.org/10.3390/ d12010019

Wieser W (1954) Free-living marine nematodes II. Chromadoroidea. Lunds Univ årsskrift n.f, avd 2 50:148

Wieser W (1959) A collection of marine nematodes from Japan. Seto Mar Biol Lab 4:159-181

Publisher's note Springer Nature remains neutral with regard to jurisdictional claims in published maps and institutional affiliations. 